\title{
Front Matter: Volume 7882
}

, "Front Matter: Volume 7882," Proc. SPIE 7882, Visual Information Processing and Communication II, 788201 (31 January 2011); doi: 10.1117/12.888820

EDIE Event: IS\&T/SPIE Electronic Imaging, 2011, San Francisco Airport, California, SPIE. United States 
PROCEEDINGS

IS\&T / SPIE

Electronic

Imaging

SCIENCE AND TECHNOLOGY

\section{Visual Information Processing and Communication II}

Amir Said

Onur G. Guleryuz

Robert L. Stevenson

Editors

25-26 January 2011

San Francisco, California, United States

Sponsored and Published by

IS\&T-The Society for Imaging Science and Technology

SPIE 
The papers included in this volume were part of the technical conference cited on the cover and title page. Papers were selected and subject to review by the editors and conference program committee. Some conference presentations may not be available for publication. The papers published in these proceedings reflect the work and thoughts of the authors and are published herein as submitted. The publishers are not responsible for the validity of the information or for any outcomes resulting from reliance thereon.

Please use the following format to cite material from this book:

Author(s), "Title of Paper," in Visual Information Processing and Communication II, edited by Amir Said, Onur G. Guleryuz, Robert L. Stevenson, Proceedings of SPIE-IS\&T Electronic Imaging, SPIE Vol. 7882, Article CID Number (2011).

ISSN 0277-786X

ISBN 9780819484192

Copublished by

SPIE

P.O. Box 10, Bellingham, Washington 98227-0010 USA

Telephone +1 3606763290 (Pacific Time) · Fax +1 3606471445

SPIE.org

and

IS\&T-The Society for Imaging Science and Technology

7003 Kilworth Lane, Springfield, Virginia, 22151 USA

Telephone +1 7036429090 (Eastern Time) · Fax +1 7036429094

imaging.org

Copyright (C) 2011, Society of Photo-Optical Instrumentation Engineers and The Society for Imaging Science and Technology.

Copying of material in this book for internal or personal use, or for the internal or personal use of specific clients, beyond the fair use provisions granted by the U.S. Copyright Law is authorized by the publishers subject to payment of copying fees. The Transactional Reporting Service base fee for this volume is $\$ 18.00$ per article (or portion thereof), which should be paid directly to the Copyright Clearance Center (CCC), 222 Rosewood Drive, Danvers, MA 01923. Payment may also be made electronically through CCC Online at copyright.com. Other copying for republication, resale, advertising or promotion, or any form of systematic or multiple reproduction of any material in this book is prohibited except with permission in writing from the publisher. The CCC fee code is $0277-786 \mathrm{X} / 11 / \$ 18.00$.

Printed in the United States of America.

Paper Numbering: Proceedings of SPIE follow an e-First publication model, with papers published first online and then in print and on CD-ROM. Papers are published as they are submitted and meet publication criteria. A unique, consistent, permanent citation identifier (CID) number is assigned to each article at the time of the first publication. Utilization of CIDs allows articles to be fully citable as soon they are published online, and connects the same identifier to all online, print, and electronic versions of the publication. SPIE uses a six-digit CID article numbering system in which:

- The first four digits correspond to the SPIE volume number.

- The last two digits indicate publication order within the volume using a Base 36 numbering system employing both numerals and letters. These two-number sets start with 00, 01, 02, 03, 04, 05, 06, 07 , 08, 09, OA, OB ... OZ, followed by 10-1Z, 20-2Z, etc.

The CID number appears on each page of the manuscript. The complete citation is used on the first page, and an abbreviated version on subsequent pages. Numbers in the index correspond to the last two digits of the six-digit CID number. 


\section{Contents}

vii Conference Committee

IMAGE AND VIDEO CODING

788203 A hybrid video codec based on extended block sizes, recursive integer transforms, improved interpolation, and flexible motion representation (Invited Paper) [7882-02] M. Karczewicz, P. Chen, R. Joshi, X. Wang, W.-J. Chien, R. Panchal, M. Coban, I. S. Chong, Y. A. Reznik, Qualcomm Inc. (United States)

788204 Achieving H.264/AVC performance using distributed video coding combined with superresolution [7882-03]

R. Klepko, D. Wang, G. Huchet, Communications Research Ctr. Canada (Canada)

788205 Real-time priority-aware transfer of SVC encoded video over MIMO communications system [7882-04]

D. Radakovic, Y. Yao, R. Ansari, Univ. of Illinois at Chicago (United States)

788206 Optimal power allocation and joint source-channel coding for wireless DS-CDMA visual sensor networks [7882-05]

K. Pandremmenou, L. P. Kondi, K. E. Parsopoulos, Univ. of loannina (Greece)

\section{IMAGE AND VIDEO PROCESSING I}

788207 A device and an algorithm for the separation of visible and near infrared signals in a monolithic silicon sensor (Invited Paper) [7882-06]

G. Langfelder, Politecnico di Milano (Italy); T. Malzbender, Hewlett-Packard Labs. (United States); A. F. Longoni, F. Zaraga, Politecnico di Milano (Italy)

788208 Localization of buildings with a gable roof in very high-resolution aerial images [7882-07] L. Hazelhoff, P. H. N. de With, CycloMedia Technology B.V. (Netherlands) and Technische Univ. Eindhoven (Netherlands)

788209 Impact of near-lossless and lossy coding on information extraction from hyperspectral data [7882-08]

A. Miguel, Seattle Univ. (United States)

7882 OA Motion adaptive Kalman filter for super-resolution [7882-09]

M. Richter, F. Naße, H. Schröder, Technische Univ. Dortmund (Germany)

7882 OB Hyper-cube watermarking scheme [7882-10]

M. Chaumont, Univ. of Nîmes (France) and Lab. LIRMM, CNRS, Univ. of Montpellier II

(France); D. Goudia, W. Puech, Lab. LIRMM, CNRS, Univ. of Montpellier II (France) 
7882 OC A joint JPEG2000 compression and watermarking system using a TCQ-based quantization scheme [7882-11]

D. Goudia, Lab. LIRMM, CNRS, Univ. of Montpellier II (France) and Mohamed Boudiaf Univ. of Science and Technologie of Oran (Algeria); M. Chaumont, W. Puech, Lab. LIRMM, CNRS, Univ. of Montpellier II (France); N. Hadj Said, Mohamed Boudiaf Univ. of Science and Technologie of Oran (Algeria)

\section{MOTION AND TRACKING}

7882 OE Robust HOSVD-based multi-camera motion trajectory indexing and retrieval [7882-13] Q. Li, X. Shi, D. Schonfeld, Univ. of Illinois at Chicago (United States)

7882 OF Particle filtering with missing frames and its application to video tracking over lossy networks [7882-14]

J. Huang, D. Schonfeld, Univ. of Illinois at Chicago (United States)

7882 OG Affine image registration with curve mapping [7882-15]

Y. Li, R. L. Stevenson, Univ. of Notre Dame (United States)

$7882 \mathrm{OH} \quad$ Optimal optical flow based disparity map estimation for lossless stereo image coding [7882-16]

A. Kumar K. C., R. Darazi, B. Macq, Univ. catholique de Louvain (Belgium)

IMAGE AND VIDEO PROCESSING II

7882 Ol Background subtraction using a pixel-wise adaptive learning rate for object tracking initialization [7882-17]

K. K. Ng, E. J. Delp, Purdue Univ. (United States)

7882 0J Background estimation and update in cluttered surveillance video via the Radon transform [7882-18]

N. Conci, Univ. degli Studi di Trento (Italy); E. Izquierdo, Queen Mary, Univ. of London (United Kingdom)

7882 OK People re-identification in camera networks based on probabilistic color histograms [7882-19]

A. D'Angelo, J.-L. Dugelay, EURECOM (France)

$7882 \mathrm{OL} \quad$ Estimating the number of people in crowded scenes [7882-20]

M. Kim, W. Kim, C. Kim, Korea Advanced Institute of Science and Technology (Korea, Republic of)

7882 OM MD/PNC with feedback for heterogeneous video multicast in lossy networks [7882-21] A. K. Ramasubramonian, J. W. Woods, Rensselaer Polytechnic Institute (United States)

$7882 \mathrm{ON}$ Object-adaptive depth compensated inter prediction for depth video coding in 3D video system [7882-22]

M.-K. Kang, Gwangju Institute of Science and Technology (Korea, Republic of); J. Lee, I. Lim, Samsung Electronics Co., Ltd. (Korea, Republic of); Y.-S. Ho, Gwangju Institute of Science and Technology (Korea, Republic of) 
788200 Depth map coding based on color motion information [7882-23]

B. T. Oh, H.-C. Wey, D.-S. Park, Samsung Advanced Institute of Technology (Korea, Republic of)

7882 OP A color video compression technique using key frames and a low complexity color transfer [7882-24]

R. Agarwal, S. Gupta, V. Gude, Indian Institute of Technology Kanpur (India)

Author Index 
Downloaded From: https://www.spiedigitallibrary.org/conference-proceedings-of-spie on 25 Apr 2023

Terms of Use: https://www.spiedigitallibrary.org/terms-of-use 


\title{
Conference Committee
}

\author{
Symposium Chair
}

Sabine E. Süsstrunk, École Polyłechnique Fédérale de Lausanne

(Switzerland)

Symposium Cochair

Majid Rabbani, Eastman Kodak Company (United States)

Conference Chairs

Amir Said, Hewlett-Packard Laboratories (United States)

Onur G. Guleryuz, DoCoMo Communications Laboratories USA, Inc.

(United States)

Robert L. Stevenson, University of Notre Dame (United States)

Program Committee

John G. Apostolopoulos, Hewlett-Packard Laboratories (United States)

Vasudev Bhaskaran, Qualcomm Inc. (United States)

Mireille Boutin, Purdue University (United States)

Chang Wen Chen, University at Buffalo (United States)

Gerard de Haan, Philips Research Nederland B.V. (Netherlands)

Edward J. Delp III, Purdue University (United States)

Eric Dubois, University of Ottawa (Canada)

Frederic Dufaux, Télécom ParisTech (France)

Touradj Ebrahimi, Ecole Polytechnique Fédérale de Lausanne

(Switzerland)

Cristina Gomila, THOMSON Corporate Research (United States)

Keigo Hirakawa, University of Dayton (United States)

Marta Karczewicz, Qualcomm Inc. (United States)

Janusz Konrad, Boston University (United States)

C. C. Jay Kuo, The University of Southern California (United States)

Dan Lelescu, Micron Technology, Inc. (United States)

Ligang Lu, IBM Thomas J. Watson Research Center (United States)

Peyman Milanfar, University of California, Santa Cruz (United States)

Antonio Ortega, The University of Southern California (United States)

Thrasyvoulos N. Pappas, Northwestern University (United States)

William A. Pearlman, Rensselaer Polytechnic Institute (United States)

Fernando Pereira, Universidade Técnica de Lisboa (Portugal)

Béatrice Pesquet-Popescu, Télécom ParisTech (France)

Majid Rabbani, Eastman Kodak Company (United States)

Dan Schonfeld, University of Illinois at Chicago (United States) 
Gaurav Sharma, University of Rochester (United States)

Andrew G. Tescher, AGT Associates (United States)

Anthony Vetro, Mitsubishi Electric Research Laboratory (United States)

John W. Woods, Rensselaer Polytechnic Institute (United States)

Xiaolin Wu, McMaster University (Canada) 